Lidia Kuchtówna*

\title{
Wilama Horzycy toruński teatr narodowy
}

DOI: http://dx.doi.org/10.12775/LC.2018.023

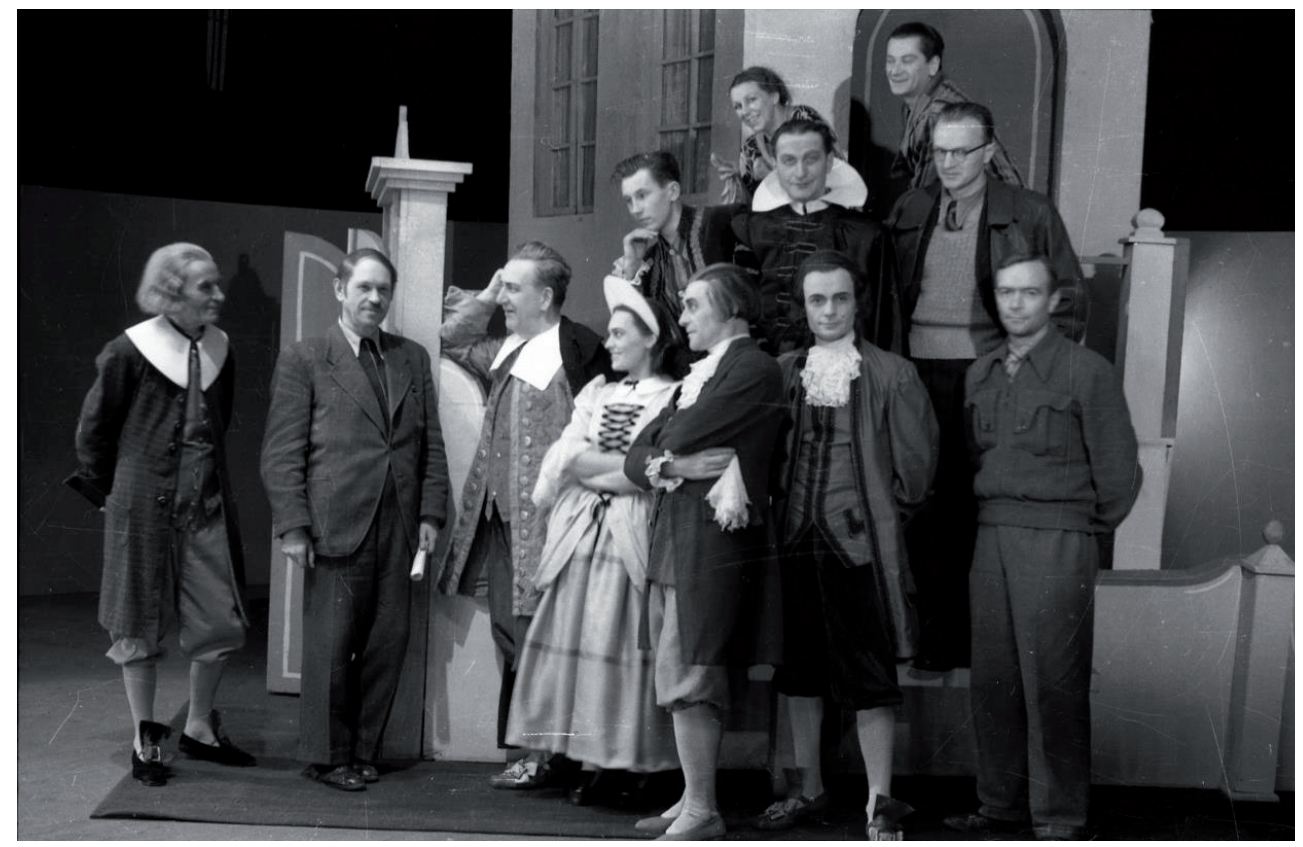

Wilam Horzyca (drugi od lewej)

z zespołem twórców spektaklu Szkoła żona Moliera (prem. 22 grudnia 1945 r.)

Fot. Alojzy Czarnecki. Archiwum Biblioteki Głównej UMK w Toruniu

\footnotetext{
* Profesor Instytutu Sztuki Polskiej Akademii Nauk. Zainteresowania badawcze: historia polskiego i europejskiego teatru XX wieku, problematyka inscenizacji, aktorstwa i scenografii, biografie artystów, edytorstwo pism teatralnych. E-mail: lidia.kuchtowna@ispan.pl.

1 Analizę trzech toruńskich sezonów Horzycy zawiera monografia: L. Kuchtówna, Wielkie dni małej sceny. Wilam Horzyca w Teatrze Ziemi Pomorskiej w Toruniu 1945-1948, Wrocław 1972.
} 
Władysławie Brackim i Aleksandrze Rodziewiczu. Musiał nie tylko skompletować zespół artystyczny, aktorski i reżyserski, lecz również zorganizować materialne podstawy teatru. Piękny gmach wprawdzie ocalał w czasie działań wojennych, ale całkowitemu zniszczeniu uległy magazyny i pracownie teatralne.

Kiedy przyszedł do Teatru Ziemi Pomorskiej, miał już pięćdziesiąt sześć lat i był osobowością twórczą znaną w całej Polsce, a działał na wielu polach. Zaczynał po I wojnie światowej od pracy literackiej. Pisał poezje, recenzje, eseje, przekładał z języka angielskiego i niemieckiego, wchodził w skład grupy poetyckiej Skamander, w dwudziestoleciu międzywojennym redagował czołowe pisma literackie - „Drogę” i „Pion”, wykładał historię dramatu i teatru powszechnego w Państwowej Szkole Dramatycznej w Warszawie. Miał też w biografii przynależność do Legionów Polskich, potem pracę w Ministerstwie Spraw Wojskowych, w kadencji 1930-1935 był posłem w Sejmie Ustawodawczym z ramienia Bezpartyjnego Bloku Współpracy z Rządem.

Przy tych rozlicznych działaniach jako priorytet swojej twórczości dość wcześnie obrał sztukę teatru, a zaczął od pracy w głośnym Teatrze im. Bogusławskiego w Warszawie. Kierował nim wraz z Leonem Schillerem i Aleksandrem Zelwerowiczem w latach 19241926, współtworząc styl teatru monumentalnego, który stał się jednym z nurtów XXwiecznej europejskiej Wielkiej Reformy teatralnej na gruncie teatru polskiego. Schiller i Horzyca złączyli w tej koncepcji tradycję dramatu romantycznego, teorie teatralne Adama Mickiewicza i twórczość dramatyczną Stanisława Wyspiańskiego. Miał to być teatr odświętny, wyzwolony z wszelkiej powszedniości, w kształcie wywiedzionym z potężnych wizji polskich romantyków. Kult dla polskiego dramatu romantycznego zespolono z radykalną nowoczesnością inscenizacji, szczególnie w spektaklach Schillera. Z poetyckiego listu Wyspiańskiego do Adama Chmiela: „Teatr mój widzę ogromny, wielkie powietrzne przestrzenie" wyprowadzono różnorakie formy teatru świątynnego, podniosłego w nastroju, poetyckiego, mieszczącego ducha narodowego. Powoływano się na Lekcję XVI Mickiewicza, profetyczny wykład, w którym poeta wskazywał na anachroniczność pudełkowych budowli teatralnych, nieprzydatnych do scenicznej realizacji wielkiej poezji dramatycznej.

Inscenizacje Schillera stanowiły najwybitniejsze przykłady teatru monumentalnego, natomiast Horzyca był głównym teoretykiem i największym propagatorem tego stylu. Kiedy w grudniu 1931 roku na sześć sezonów objął dyrekcję Teatrów Miejskich we Lwowie, świadomie - we współpracy z Andrzejem Pronaszką, Władysławem Daszewskim, Edmundem Wiercińskim, Wacławem Radulskim - kontynuował działalność zapoczątkowaną w Teatrze im. Bogusławskiego. Od razu zaproponował Schillerowi reżyserię Dziadów Mickiewicza, a w repertuarze scen lwowskich umieścił utwory leżące na linii teatru narodowego, począwszy od Odprawy postów greckich Jana Kochanowskiego i Potrójnego Cieklińskiego, przez Sen srebrny Salomei, Samuela Zborowskiego i Księdza Marka Juliusza Słowackiego, Kleopatrę Norwida, Nie-Boską komedię Krasińskiego, Wesele, Powrót Odysa i Wyzwolenie Wyspiańskiego, aż do Marchołta Jana Kasprowicza. Repertuar oparł również na sztukach współczesnych autorów polskich, a obok nich - dramatopisarzy reprezentatywnych dla nowych kierunków w dramacie europejskim, takich jak Shaw, Pirandello, Chesterton, O’Neill, Brecht, Tretiakow, Marinetti. Inspirował wiele przedstawień, opatrywał je komentarzami, wydawał pismo „Scena Lwowska”, opracował też kilka inscenizacji: Kleopatrę Cypriana Norwida, Wyzwolenie Wyspiańskiego i Odprawę postów greckich 
Kochanowskiego. Łatwo odszukać w nich wizję zmonumentalizowaną przez podesty i konstrukcję terenu gry, patos i statyczność, stylizowane kostiumy.

Po ważkiej artystycznie dyrekcji lwowskiej Horzyca w 1937 roku wszedł w skład kierownictwa Teatru Narodowego i Nowego w Warszawie. Zamierzał kontynuować swoją dotychczasową linię programową, w zapowiedziach umieścił Bolestawa Śmiałego oraz Skatkę Wyspiańskiego, Irydiona Zygmunta Krasińskiego, Lillę Wenedę Słowackiego, Hamleta Williama Szekspira. Z repertuaru lwowskiego przeniósł na scenę Narodową Człowieka, który byt Czwartkiem Gilberta K. Chestertona i Czarna Damę z sonetów George’a Bernarda Shawa. W ciągu dwóch sezonów, zamkniętych cezurą września 1939 roku, wystawił Balladynę i Mazepę Słowackiego, Dożywocie Aleksandra Fredry, Skiza Gabrieli Zapolskiej, Szkotę obmowy Richarda B Sheridana i Nasze miasto Thorntona Wildera. W swojej reżyserii zrealizował trzy jednoaktówki: Miłość czysta u kąieli morskich Norwida, Odwiedziny o zmroku Tadeusza Rittnera i Czasu jutrzennego Józefa Czechowicza.

Lata wojny spędził w Warszawie. Pracował jako tłumacz w Urzędzie Miejskim, wykładał historię literatury na tajnych kursach, współredagował konspiracyjne pismo „Nurt”, dużo pisał (wszystkie rękopisy spłonęły w czasie powstania warszawskiego). Po wyzwoleniu natychmiast powrócił do pracy teatralnej. Z Karolem Adwentowiczem sprawował przez krótki czas kierownictwo Teatru im. Wyspiańskiego w Katowicach, a po przesiedleniu do Katowic zespołu lwowskiego objął dyrekcję teatru w Toruniu.

Dopiero tutaj, w Teatrze Ziemi Pomorskiej w jego inscenizacjach doktryna teatru monumentalnego znalazła pełniejszą realizację. Zawsze był monolityczny w swoich dążeniach i wizjach teatralnych. W warunkach powojennej mizerii, w niewielkim, zniszczonym i ubogim mieście działał tak, jak w dotychczasowych prężnych środowiskach kulturalnych. Próbował wrócić do przedwojennego porządku etycznego i poprzednich koncepcji artystycznych, wcześniejszych postulatów i wyborów. Na przekór zewnętrznym utrudnieniom konsekwentnie realizował zamiar zorganizowania w Toruniu instytucji artystycznej na kształt Teatru Narodowego.

W różnego rodzaju wypowiedziach określił, jaką rolę powinien pełnić teatr, noszący miano „narodowy”. Tłumaczył w sposób aż patetyczny, że jest on spadkobiercą wielkiej tradycji, bo ma za sobą okres, kiedy odgrywał rolę świątyni polskiej kultury i polskiej mowy. Jest powołany do stanowienia skarbnicy wartości duchowo-artystycznych wielkiej sztuki polskiej. Winien przybliżać tradycję, wprowadzając na scenę kanon najwybitniejszych osiągnięć dramatu polskiego, a także światowego. Idąc za wskazaniem Norwida, ma obowiązek „organizowania wyobraźni narodowej”. Ma być zwierciadłem aktualnych zagadnień społecznych, politycznych i kulturalnych, nurtujących współczesne społeczeństwo, i funkcją duchowego życia narodu.

Model polskiego teatru narodowego porównywał z wybitnymi teatrami Europy, a przede wszystkim z Comédie Française, najstarszą sceną, noszącą cechy charakteru narodowego, a więc $\mathrm{z}$ teatrem aktorskim ze stałym repertuarem tradycyjnym i współczesnym, stawiającym sobie za cel pielęgnowanie języka literackiego. Wskazywał również na wiedeński Burgtheater, którego tradycję cechują staranny dobór repertuaru, wysoki poziom aktorstwa, troska o kulturę języka. Także na moskiewski Teatr Mały i jego ważną rolę w rozwoju rosyjskiej kultury narodowej².

2 Horzyca najpełniej określił swoje poglądy na Teatr Narodowy w liście do ministra kultury i sztuki Tadeusza Galińskiego, z 3 IX 1958 (Horzyca 1991: 436). 
W repertuarze toruńskiej dyrekcji zawarł Horzyca swoje marzenia i przemyślenia, pasje oraz głęboką wiarę w prawdy objawiane przez poetów, a w inscenizacjach - dążenie do urealnienia teatru monumentalnego. Najpełniejszym wyrazem jego przekonań artystycznych stała się prapremiera Za kulisami, fantazji dramatycznej ukochanego poety Norwida. Z klasyki polskiej udało się Horzycy zrealizować jedynie Wesele Wyspiańskiego, a z nowszych utworów Wilki w nocy Rittnera, Pastoratkę Schillera i Dewaluację Klary PawlikowskiejJasnorzewskiej. Z wielkiego dramatu europejskiego grano Sen nocy letniej oraz Romea i Julię Szekspira, Życie snem Calderona i Szkołę żon Moliera. Z repertuaru rosyjskiego Ożenek Mikołaja Gogola i dwie jednoaktówki: Mozarta i Salieriego Aleksandra Puszkina oraz Pugaczowa Siergieja Jesienina. Z europejskiego dramatu współczesnego utwory rzadko pojawiające się na scenie - Major Barbarę, Cezara i Kleopatrę, Czarna Damę z sonetów Shawa, Magię Chestertona, Rozkosz uczciwości Luigiego Pirandella. Podobnie jak w teatrze lwowskim Horzyca chętnie realizował premiery współczesnych polskich pisarzy. Wystawił Orfeusza Anny Świrszczyńskiej, Promienistych Krystyny Grzybowskiej, Stara cegielnię i Gospodarstwo Jarosława Iwaszkiewicza, Sa rzeczy ważniejsze Janusza T. Dybowskiego. Ważnym spektaklem stały się Dwa teatry Jerzego Szaniawskiego z gościnnym występem Adwentowicza, a przedstawienia Orfeusza, Promienistych i Gospodarstwa były prapremierami. W budowaniu repertuaru nie sięgał po dramaty o charakterze propagandowym, nie reagował na charakterystyczne dla czasów powojennych tendencje polityczne i społeczne.

Publiczność teatralną, zainteresowaną poetyckim repertuarem stanowili pracownicy uniwersytetu, miejscowa inteligencja, studenci i młodzież szkolna, natomiast przeciętny widz toruński tęsknił za operetką, wstawkami muzycznymi i komedią. Toteż Horzyca musiał ze względów frekwencyjnych i finansowych, także dla uniknięcia monotonii, wprowadzać do repertuaru sztuki rozrywkowe. Miał zresztą duże zrozumienie dla komizmu, groteski i dowcipu, a widowiska muzyczne wystawiał z wielkim smakiem. Grano więc Króla włóczęgów Justina McCarthy’ego i Nitouche Hervégo, komedię sensacyjną Seans Noëla Cowarda, Ładna historię Gastona A. de Caillaveta i Roberta de Flersa, Walkę kobiet Scribe’a i Ernesta Legouvéa, a nawet komedyjki o małej wartości literackiej: Musisz być moja Verneuilla i Szczęśliwe dni Claude’a A. Pugeta. Torunianie zobaczyli też klasyczne komedie: Maż i żona, Nikt mnie nie zna, Gwałtu, co się dzieje i Koncert Fredry oraz Michała Bałuckiego Grube ryby i Dom otwarty.

Tylko w projektach i zamierzeniach pozostało wiele interesujących pozycji. Nie udało się z różnych powodów zrealizować Snu srebrnego Salomei Słowackiego, Wyzwolenia i Bolestawa Śmiatego Wyspiańskiego, Hamleta Szekspira, Wachlarza Carla Goldoniego, Człowieka i nadczłowieka Shawa, chińskiej sztuki Hsiunga Pani Wdzięczny Strumień, Wielkiego Fryderyka ani Cezara i człowieka Adolfa Nowaczyńskiego, Don Juana Moliera, Ladacznicy z zasadami JeanPaula Sartrea, Maskarady Iwaszkiewicza, dramatu antycznego, co było przedmiotem rozmów z wybitnym filologiem klasycznym prof. Stefanem Srebrnym, ani wielu innych sztuk.

Spektakle Horzycy cechowała jednolita poetyka. Stworzył pewien model teatru wyobraźni, niezwiązanego z konkretnymi sztukami: teatr odchodzący od naturalizmu i iluzji, często statyczny, zmonumentalizowany, poetycki i kontemplacyjny. Najważniejszy element spektaklu stanowiło słowo, często podawane w sposób inkantacyjny, recytacyjny, upodabniający teatr do obrzędu. Magię słowa wydobywała ascetyczna scenografia, wykorzystująca światło jako ważny środek kompozycyjny, często jednoczesna jak w misteriach średniowiecznych. 
Wielokrotnie w inscenizacjach ujawniał Horzyca swoją ogromną erudycję teatralną, a na pewno najpełniejszym wyrazem jego przemyśleń i dążeń, subtelnej ironii i gorzkiej myśli było wystawienie fantazji dramatycznej Za kulisami. Decydując się na prapremierę, w sto dwudziestą piątą rocznicę śmierci Norwida, musiał sam opracować tekst dramatu, który doszedł do nas w postaci luźnych fragmentów maskaradowego dramatu Za kulisami i antycznego Tyrteja. Horzyca uznał Tyrteja za utwór poety Omegitta i równocześnie wizję uczestników zabawy maskaradowej, która prawem kontrastu wdziera się do sal redutowych. Odczytał dramat Norwida przez analogię do Wesela Wyspiańskiego ${ }^{3}$.

Tyrteja i Za kulisami pokazał w dekoracji Leonarda Torwirta jako całość, bez opuszczania kurtyny. Część maskaradowa rozgrywała się w sali balowej, zamkniętej trójdzielną ścianą składającą się z wielkich luster o szarosrebrzystym połysku. U sufitu wisiały trzy duże świeczniki. Scenę podzielono na dwie płaszczyzny. W pobliżu rampy, na pierwszym planie jaskrawo oświetlonym, przewijające się grupki uczestników maskarady wygłaszały swoje krótkie dialogi. Dalsza płaszczyzna sceny tonęła w niebieskawym półmroku. Przez cały czas przewijały się przez nią tańczące pary w stylowych kostiumach, niknąc lub pojawiając się to z lewej, to z prawej strony. Sceny balowe opływal sentymentalny walc Kreislera, obezwładniający monotonią.

Świat Tyrteja wdzierał się do sali balowej gwałtownie przez ścianę, która się nagle rozsuwała wśród trzasku i brzęku rozbitych luster. Przestraszeni goście uciekali w popłochu, a na pustą scenę wkraczały postaci w stylizowanych kostiumach greckich. Tyrtej rozgrywał się bez dekoracji, w matowym świetle horyzontówki. Gdy kończył się, światła przygasały, po chwili rozjarzały się świeczniki i znów wracała sala balowa i pojawiały się taneczne pary. W finale Quidam już na opustoszałej scenie wygłaszał wiersz Norwida, zaczynający się od słów „Na posadzkę zapustnej sceny...”; wiersz o tańczących maskach, kwiecie papierowym i łzie z wosku.

Wystawiając Orfeusza Świrszczyńskiej, ze średniowiecznych misteriów wywiódł Horzyca scenę jednoczesną, gdzie w syntetycznej dekoracji obok poszczególnych zmieniających się fragmentów istniała przestrzeń neutralna - „campus”. Tak więc w pierwszym akcie zasadniczy element zabudowy scenicznej stanowiła kondygnacja schodów z przedpolem. Z przodu mieściła się po prawej stronie kawiarnia, po lewej na podeście - sypialnia Eurydyki. W głębi zaznaczono skały, wśród których Orfeusz spotykał się z menadami.

Drugi akt rozpoczynał się przed zamkniętą srebrną bramą piekieł. Gdy ukazywał się Hades, na najwyższej środkowej partii srebrno oświetlonych schodów siedziała królowa piekieł Persefona. Kiedy wstawała, jej szafirowo-stalowa suknia spływała po schodach, niezmiernie wydłużając hieratyczną i wyniosłą postać. W głębi sceny na tle ciemnych niebiesko naświetlonych kotar zawieszono ukosem żelazny most, z którego Hermes pokazywał Orfeuszowi świat podziemny - dusze w białych całunach kroczące ku wodzie letejskiej i chór grzeszników w ogniu czyśćcowym, wystylizowany na ikonografii średniowiecznej: pod mostem na czarnym tle ukazywały się ramiona, czerwono oświetlone, chwiejące się w czasie recytacji jak płomienie. Cały Hades tonął w niebieskawym półmroku, twarze i ciała bogów miały kolor srebrny, szaty - granatowo-liliowy.

3 Układ tekstu Za kulisami, zaproponowany przez Horzycę, wywołał żywą dyskusję i nie został zaakceptowany przez badaczy twórczości Norwida. Wypowiadali się na ten temat: Irena Sławińska, Tadeusz Makowiecki, Juliusz Wiktor Gomulicki i Kazimierz Braun. 
W akcie trzecim dekorację stanowiły schody i umieszczone na nich skały, wśród których w świetle błyskawic rozszarpywały Orfeusza szalone menady, jednakowo ubrane w skóry, wszystkie z długimi czarnymi włosami, mówiące chórem, poruszające się rytmicznie i ekspresywnie.

Kurtynę między poszczególnymi scenami zastępowało wyciemnienie i muzyka. W ten sposób osiągnięto wrażenie „scenicznego rapsodu. [...] Nakazowi poezji - pisał Horzyca - poddałem [...] także i grę aktorską. [...] Dialog zasadniczo oparty był nie na logice konwersacji, lecz na logice muzyki” (Horzyca 1946). W Orfeuszu zobaczył problemy ponadczasowe, istotne dla ludzi antyku i ludzi współczesnych, podkreślając patos liryzmu, dając wyraz wiary w podniesienie się duchowe po tragicznym doświadczeniu wojennym.

Jeszcze innego rodzaju erudycja teatralna znalazła wyraz w przestawieniach szekspirowskich, nawiązujących do teatru elżbietańskiego, znanego z rysunku Jana de Wittea. Horzyca nie wprowadził wiernej rekonstrukcji sceny z czasów Stratfordczyka, lecz przystosował scenę elżbietańską do wymogów i warunków teatru współczesnego.

W Śnie nocy letniej w scenografii Torwirta rozegrał akcję na dwóch kondygnacjach ogromnych srebrnych schodów, wygiętych w podkowę i w głębi zamkniętych ekranem. Taka architektura sceny oznaczała pałac królewski Tezeusza. Na tych samych schodach w aktach następnych wyrastał las: drzewa, krzewy i paprocie o fantastycznych, dużych i płaskich liściach. Światłem, a był to środek nieznany teatrowi elżbietańskiemu, wydobywano różnicę poziomów, wyodrębniano poszczególne kondygnacje.

Element nowatorski stanowiły kostiumy postaci, odwolujące się do wyobraźni Wyspiańskiego, łączącej elementy obcych sobie światów i epok. Bogów szekspirowskich pokazano przez pryzmat wyobrażeń słowiańskich z kręgu Świtezianki czy Goplany, Puka w kubraczku pasterskim, a obok nich - Ateńczyków w antycznych zbrojach i chlamidach. Przedstawienie było wyraźną opozycją do operowej rewii i feerii Reinhardta, który w sławnym berlińskim przedstawieniu Snu nocy letniej stopił naturalizm z wyobraźnią romantyczną. U Horzycy renesansowość Szekspira zespoliła się z jasnością myśli i monumentalnym misterium patetycznym, ze świadomością, że istnienie jest „przejawem i dziełem jakichś odwiecznych sił kosmicznych” (Horzyca 1945). Oś kompozycyjną akcji stanowiło wyniesienie i upadek Spodka. Spektakl narzucał przekonanie, że w żywioł komedii, w fantastykę baśni wdarło się coś nadzmysłowego.

Również w Romeu i Julii inscenizator odwołał się do czasów elżbietańskich. Nie było dla niego sprawą istotną, że akcja toczy się w obsypanej glicyniami i różami Weronie, że pierwiastki romantyczne przeplatają się $\mathrm{z}$ warstwą renesansową. Ukazał patetyczną tragedię młodych kochanków, ich czystą miłość przeciwstawiając zepsuciu otaczającego świata. Znów zastosowal formę rapsodu, bez rozbijania utworu na odsłony, i dekorację nawiązującą do zasady stałej konstrukcji scenicznej. Składała się z trzech poziomów, które Torwirt podzielił pasami w agresywnych jaskrawych kolorach, żółtym i pomarańczowym. Poziom najwyższy służył jako balkon lub pokój Julii, poziom środkowy - jako mieszkanie, sala balowa i ogród Kapuletów. Pozostałe sceny rozgrywały się na najniższej kondygnacji, gdzie znajdował się grobowiec Kapuletów, a na nim waza z bukietem czerwonych róż. Czas akcji określały jedynie ostrołuki gotyckie, markujące okna i drzwi. Właściwe miejsce akcji wyodrębniał z całej konstrukcji snop światła o charakterze ekspresjonistycznym. 
Kochankowie podawali tekst w sposób inkantacyjny i patetyczny, czasem stosowali gest sztuczny, nierealistyczny. Kompozycje zbiorowe miały urok fresków, wynikający $\mathrm{z}$ upozowania postaci na małej przestrzeni scenicznej. Utrwalono na zdjęciu ze spektaklu fragment czwartego aktu, gdy na proscenium rozgrywał się groteskowy epizod z weselnymi muzykantami, grającymi na niemych instrumentach, a z najwyższej kondygnacji bezwładnie zwisała ręka pogrążonej w letargu Julii. Była to ulubiona scena Horzycy, przy której zawsze płakał; nawet po latach, na samo jej wspomnienie.

Program teatru o charakterze narodowym, poetyckim, monumentalnym nie mógł spotkać się w małym Toruniu z szeroką akceptacją. Co pewien czas wybuchały dyskusje, czy rzeczywiście taka scena jest potrzebna toruńskiemu społeczeństwu. Proponowano wystawianie sztuk bardziej realistycznych i aktualnych, „bez owego mistycznego czy metafizycznego balastu, który tylko obraz gmatwa i zaciemnia”, pisał dziennikarz „Ziemi Pomorskiej”. Wyjaśniał szczegółowo: „Wszyscy, których interesują problemy roztrząsane w dramatach Calderona, Świrszczyńskiej czy Norwida i którzy rozumieją te rzeczy bez komentarzy, mogą zmieścić się na jednym przedstawieniu podczas premiery” (F. M. 1947). Również nie byle kto, bo Adam Grzymała-Siedlecki, pod pseudonimem Jan z Marnowa, zaatakował politykę artystyczną Horzycy, głównie wprowadzanie na scenę poezji. Powątpiewał: „Ale czy właśnie Toruń (nie jakieś większe miasto) nadaje się na taką świątynię sztuki?” (Grzymała-Siedlecki 1948)

Natomiast świadectwa widzów niejednokrotnie przeczą tym stwierdzeniom. „Żyliśmy teatrem - pisał niedawno prof. Andrzej Tomczak, historyk i archiwista, we wspomnieniu Mój uniwersytet w latach 1946-1950. - Nie opuściliśmy żadnego spektaklu Wilama Horzycy, wybierając się na przedstawienia zwykle w kilka osób” (Tomczak 2015). Również prof. Irena Sławińska, literaturoznawca i teatrolog, podkreślała wielki udział teatru Horzycy w formacji studentów i atmosfery intelektualnej Torunia. Nawet przyznawała się do inspiracji przedstawień Horzycy w jej pasjach naukowych, m.in. w badaniach nad twórczością Norwida. Jarosław Iwaszkiewicz z sentymentem wspominał małżeństwo Horzyców ze swego pobytu w Teatrze Ziemi Pomorskiej w 1947 roku:

Oni tak bardzo pasowali do tego cichego, mądrego miasta, do uniwersyteckiego nastroju, do akademickich rozmów w tak niezwykłym domu profesora Konrada Górskiego. Wil zapalony do swojej roboty tworzył cuda i chciał tworzyć jeszcze, Stasia w swojej naiwności pasowała do miasta, do secesyjnego teatrzyku, do zapalonych ludzi. Tworzyło się wtedy w Toruniu nieprzeciętne środowisko (Iwaszkiewicz 1979: 18).

Horzyca starał się uczynić z teatru ośrodek kulturalny dla całego miasta. Jego spektaklom towarzyszyły dyskusje popremierowe, wygłaszał odczyty na czwartkach literackich, publikował artykuły w programach i w prasie, komentujące założenia inscenizacyjne i program teatru. Przez cały czas pracy w Toruniu mieszkał przy ulicy Szerokiej 24, zajmując pokój we wspólnym mieszkaniu z Marią Bołtuciową, wdową po generale Mikołaju Bołtuciu, oraz z Marią Zielińską-Puzyniną. Zainteresował teatrem dzieci współmieszkanek: Irenę Bołtuć i Konstantego Puzynę, wkrótce znanych krytyków teatralnych.

Odszedł z Teatru Ziemi Pomorskiej wbrew własnej woli. 
Do Torunia bardzo się przywiązałem - pisał do Julii Rylskiej - i wcale nie uważam, że jestem na głębokiej prowincji, jak się to wydaje wszystkim niemal moim aktorom. Mimo bowiem prowincjonalności mego teatru, dosyć o nim dziś szeroko mówią w Polsce, co świadczy, że nie jestem znów na takim odludziu (Horzyca 1991: 168).

Maśliński pamiętał, jak Horzyca „(przedwojenny człowiek stolicy!) pomrukiwał: »No cóż, proszę pana, a weźmy taki Heidelberg «” (Maśliński 1980). Kiedy rozpoczynał pracę w Toruniu, wyjawił w przemówieniu przed prapremierą Promienistych zapewne motto swoich działań: „Nie ma świata tak małego, by się z niego prawdziwa, niekłamana nieśmiertelność urodzić nie mogła, jeśli się tylko obudzi gorąca jej wola” (Horzyca 1947).

\section{Bibliografia}

F. M. 1947. „Teatr dla elity czy teatr dla mas?”. Ziemia Pomorska 283.

Horzyca, Wilam 1945. „Sen nocy letniej”. Program. Teatr Ziemi Pomorskiej w Toruniu, sezon 1945/46, nr 5.

- 1946. „O inscenizacji “Orfeusza”. Teatr 6/7.

— 1947. „Jak na 'Dziady”'. Listy z Teatru 10.

- 1991. Listy Wilama Horzycy. Oprac. Lidia Kuchtówna. Warszawa: Instytut Sztuki PAN.

Iwaszkiewicz, Jarosław 1979. „Horzyca”. W: Zdzisław Wróbel (oprac.). Wspomnienia o Wilamie Horzycy. Toruń: Toruńskie Towarzystwo Kultury.

Kuchtówna, Lidia 1972. Wielkie dni matej sceny. Wilam Horzyca w Teatrze Ziemi Pomorskiej w Toruniu 1945-1948. Wrocław: Zakład Narodowy im. Ossolińskich.

Grzymała-Siedlecki, Adam (Jan z Marnowa) 1948. „Teatry pomorskie w sezonie 1947/48”. Teatr $3-5$.

Maśliński, Józef (M.A.Styks) 1980. „Wrocław - Heidelberg”. Życie Literackie 31.

Tomczak, Andrzej 2015. „Mój uniwersytet w latach 1946-1950”. Absolwent 20. 